\title{
The Metalanguage of Corruption in Cameroon-Part I: The Registers of General Administration, Transport and Education
}

\author{
Gilbert Tagne Safotso ${ }^{1}$ \\ ${ }^{1}$ Department of English, University of Maroua, Cameroon \\ Correspondence: Gilbert Tagne Safotso, P. O. Box 282, Dschang, Cameroon. Tel: 237-677-813-172. E-mail: \\ gilbertsafotso@gmail.com
}

Received: January 3, 2015 Accepted: January 30, 2015 Online Published: March 29, 2015

doi:10.5539/ijel.v5n2p47 URL: http://dx.doi.org/10.5539/ijel.v5n2p47

\begin{abstract}
This paper analyses the metalanguage of corruption in Cameroon. Using examples from the registers of General Administration, Transport and Education, from the sociolinguistic frame, the paper shows that the widespread corruption in Cameroon has led to the development of a rich specialized language to discuss it. In the sectors of General Administration, Transport and Education, simple and neutral expressions in Cameroon French, Cameroon English and Cameroon Pidgin English have acquired subtle meanings that they need the interpretation of someone who knows the system to be fully understood. This study thus tries to throw some light on this domain so far unexplored.
\end{abstract}

Keywords: metalanguage, corruption, bribery, general administration, transport, education

\section{Introduction}

In recent years, corruption has become so rampant across the globe that for some time now a German-based NGO, Transparency International has been ranking many countries of the world according to their index of corruption. These ill practices are generally seen as the plague of the poor countries. However, from the numerous conferences organised on this phenomenon and the various tables of classification of Transparency International, it is often quite surprising (amusing) to see the rank occupied by some rich and respectable countries. For instance, in 2013, France was ranked $22^{\text {nd }}$ on 177 most corrupt countries of the world; in the same table, Germany was ranked $12^{\text {th }}$ and the UK 14th. In February 1995, Friedrich-Ebert-Stiftung organised a conference on corruption in Germany. When the papers of the conference were later published under the title "Corruption in Germany: its causes, its manifestation, and strategies to fight against it", they drew a high level of attention in the German media, and in the German society as a whole (Friedrich-Ebert-Stiftung Cameroon Report, 1999:6). Though a scourge which has already caused a lot of harm to humanity, and which has to be fought by all means, the various findings of Transparency International simply reveal that corruption is part of human being, something that exists in countries the world over.

Cameroon, which already topped the world's most corrupt countries in 1998 and 1999, was still ranked 144th on 177 most corrupt countries in 2013. This, however, let to some jubilation by the government. In 2014, the country was ranked $136^{\text {th }}$ on 175 . The score from 2012 to 2014 was virtually the same: 26 in 2012, 25 in 2013, and 27 in 2014. A rich specialized language used to talk of bribery in general, and to ask/give or receive it in all sectors of the country has therefore developed in Cameroon. To date, many studies have been conducted on this ill practice in Cameroon and on how to curb it (Ndangam, 2006; Peh \& Drori, 2010; Cerutti et al., 2012, etc.), but the specialized language used to ask/give or receive bribe has not yet drawn the attention of scholars. From the sociolinguistic frame, this paper (which is the first part of a series of two) looks at the metalanguage of corruption in the sectors of general administration, transport and education in Cameroon, to show how simple words and expressions can have very subtle meanings in this context.

\section{Short Presentation of the Cameroonian Linguistic Landscape}

The Cameroonian linguistic landscape is very complex. With its 239 local languages (Mba, 2009, p. 551), Pidgin English (Todd, 1974; Ferral, 1976; Mbangwana, 1983; Ayafor, 1996 \& 2000; Menang, 2004; Atechi, 2011), Camfranglais (Tiayon Lekobou, 1985; Lobe Ewane, 1989; Chia, 1990; Biloa, 1999; Kouega, 2003, etc.), and the two official languages, namely French and English, Cameroon is among the most linguistically complex 
countries of Africa. Only the Democratic Republic of Congo, with about 250 home languages, has so high a number.

In Cameroon, 239 local languages co-exist and are spoken by various ethnic communities to transmit their cultural heritage. But apart from some vehicular languages such as Fulfulde (Note 1) and Ewondo (Note 2) which cross the boundaries of many ethnic communities, the vast majority of Cameroonian home languages are restricted to small areas where they are spoken by a few people. Mba (2009) reports that, since 1967 a number of mission institutions have been devoting individual efforts to teach some of the local languages in their schools, but the only hope for some of these languages to survive is to effectively teach the ones recently selected by the Ministry of Secondary Education in all the schools across the country. Unlike the indigenous languages which are still almost all in their dormant state, Pidgin English is the sole lingua franca of Anglophone and Francophone Cameroonians. Mbangwana (1983, p. 83) remarks that in Cameroon, pidgin English is the language of buying and selling; the language of making jokes, singing humorous obscene work songs, posing and solving riddles, and storytelling; it is the driver's language in motor park transactions and on board the vehicle, and also a very important language of the nursery. Ayafor $(2005$, p. 5$)$ emphatically points out that it is "the ultimate unifying common language for Cameroon".

Though having a very imbalanced number of speakers around the country, since 1961, date of the reunification of French and British Cameroon, French and English are the two official languages of the country. But French has always played a dominant role because of the important number of its speakers. According to the 2010 census, the population of the eight French-speaking regions of Cameroon represents $83.56 \%$ of the country's population, leaving only $16.44 \%$ to the two English-speaking areas. At school, French is used as the medium of formal instruction in the Francophone subsystem of education, and taught as a foreign language in the Anglophone subsystem. English is used as the medium of formal instruction in the Anglophone subsystem of education, and taught as a foreign language in the Francophone subsystem. In administration, French is the dominant language. The high number of French-speaking Cameroonians explains why many expressions as we shall see in the data are from French.

Camfranglais, which is a hybrid language used by the youth, has been existing in Cameroon for over thirty years (Lobe Ewane, 1989; Chia ,1990; Ntsobe et al., 2008). This language draws its lexis from French, English, Pidgin English, local languages, and other European languages. This language has captured the attention of many researchers, and its codification is quite advanced (Feral, 2006). A similar language called Nouchi can be found in Ivory Coast. Its lexis is drawn from French, Dioula, and other indigenous or European languages (Quefelec, 2005). This brief description of the complexity of the linguistic landscape of Cameroon is a premise of what a metalanguage of corruption can be in this setting, where corruption is so rampant (see Firiedrich-Ebert-Stiftung Cameroon Report, 1999).

\section{Methods}

The data analysed come from randomly carried out talks with civil servants and service seekers of various ministries, their regional and divisional delegations, especially the ministries of Finance, Secondary Education, Basic Education and Territorial Administration, which are the ministries in which corruption touches almost all citizens. Every parent normally sends his child to school; and every good citizen pays his taxes and has his documents signed by a Divisional or Sub Divisional Officer. The data was also collected through informal interviews with students and some agents on university campuses, as well as with passengers and drivers during journeys. This type of interview was adopted because of the suspicion and precautions that surround corruption issues in Cameroon. Very few respondents would have accepted a formal interview or to fill in a questionnaire because of the fear that they could be taken as corrupt, or that the investigator may be a police agent. The civil servants, services seekers, students, parents, university agents, drivers and passengers involved had to list the various words, phrases and sentences civil servants and uniform officers use when they ask for bribe. They also had to say what they say when they indulge into bribery. The various answers gathered are analysed below.

\section{Results}

The data will be analysed under three headings: (1) the specialized language used to talk of corrupt practices and bribery in general, (2) the language used to ask/give bribe, and (3) the language used to receive it. Each time, the word, phrase or sentence is given in Cameroon French, Cameroon Pidgin English or Cameroon English. Then, their Standard British English versions are supplied. 


\subsection{Special Use of Language to Talk of Corrupt Practices and Bribery in General in Cameroon}

As the tables below illustrate, the rich repertoire used to talk of corrupt practices and bribery is drawn from a variety of sources.

Table 1. Specialized language used to talk of corruption in general in Cameroon French

\begin{tabular}{ll}
\hline Utterances & Standard British English version \\
\hline L'épervier l'a pris(e). & The sparrowhawk caught him. \\
Il est éperviable. & He is susceptible to be caught by sparrowhawk. \\
C'est hautement gombotique. & It is highly full of gombo*. \\
La CONAC va réagir. & The National Commission for the fight Against Corruption will react. \\
C'est un bon tuyau. & It's a good channel. \\
Il est tombé sur un bon réseau. & He fell on a reliable network. \\
Il a des godasses. & He has boots. \\
Il les a bien motivés. & He motivoted them well. \\
Il les avait vus avant. & He had seen them before. \\
Elle avait bien parlé. & She had spoken well. \\
\hline
\end{tabular}

Gombo*: slimy tropical vegetable used in many sauces.

It can be remarked that, apart from "The National Commission for the fight Against Corruption will react", none of the sentences above mentions the word corruption. It is also important to note that very few Cameroonians can give the full meaning of the acronym CONAC either in French or in English. All they know is that it denounces acts of corruption in the country. Table 2 below illustrates some of the language used to talk of corruption in general in Cameroon Pidgin English.

Table 2. Specialized language used to talk of corruption in general in Cameroon Pidgin English

\begin{tabular}{ll}
\hline Utterances & Standard British English version \\
\hline e done oil yi, mop. & He has oiled his mouth. \\
Na man know man tin. & It's a business in which one needs to know someone. \\
Got de chop fo place whe dem tie yi. & Goat grazes where it has been tied. \\
e done tok fine. & He has spoken well. \\
Dem done see big man. & They have seen the boss/the responsible/ the director \\
e done do back back. & He gave something secretly. \\
CONAC don arrest yi. & The National Commission for the fight Against Corruption arrested him. \\
Dem go lock yi mop. & They will shut his mouth. \\
Dem done lock yi hand. & They have closed his hands. \\
e done wipe yi mop. & He has cleaned his mouth. \\
e done cover yi mop. & He has covered his mouth. \\
\hline
\end{tabular}

As in Table 1, except the acronym CONAC which refers to corruption, all the other expressions look so neutral. For example, "he has spoken well" in its conceptual meaning can simply refer to a ceremony where someone has delivered a good speech.

Cameroon English expressions used to talk of corruption include "fuel his/her car", "putting some weigh to a file", "locking somebody's mouth", "bringing a goat", etc. These phrases, in fact, do not denote anything relating to corruption. Any other English speaker around the world would, for example, understand "fuel his/her car" and "bringing a goat" as "putting some petrol in somebody's car" and "taking a goat from a place to another". Yet, almost all English-speaking Cameroonians would accurately interpret the full meaning of these phrases, and would say that they belong to the register of corruption. Unlike Cameroon French and Cameroon Pidgin English, it can be noted that there are very few English expressions used to talk of corruption practices in Cameroon. Anglophone Cameroonians usually prefer to use Pidgin English to discuss sensitive matters. The only option to francophone Cameroonians is French.

Cameroonians also mix codes to talk of corruption. They mix French and English, French and mother tongue or French, Pidgin English and English as illustrated by the following examples: "he gave gombo to get it", "il a choko", "find me réseau", "he lancer yi something" (meaning he bribed to have it; he bribed; find me people who 
take bribe; he gave him some bribe). Section 4.2 below looks at the metalanguage used to ask for bribe in general administration.

\subsection{Specialized Language Used to Ask for Bribe in General Administration, Transport and Education}

As in Section 4.2, the analysis looks at the language drawn from Cameroon French, Pidgin English and Cameroon English.

Table 3. Specialized language used to ask for bribe in general administration in Cameroon French

\begin{tabular}{ll}
\hline Utterances & Standard British English version \\
\hline Finis avec moi. & End it with me. \\
Parle bien. & Talk well. \\
Lance-nous. & Throw us something. \\
Salue-moi. & Greet me. \\
Paye mon bic/ le papier. & Buy my pen/ some papers. \\
Motive-nous. & Motivate us. \\
Il faut parler. & Talk. \\
Il faut te comporter. & Bahave yourself. \\
Il faut le vin du patron. & There should be the boss's wine. \\
Va réfléchir. & Go and think. \\
Fais quelque chose. & Do something. \\
Les renseignements se paient. & Inquiries are paid for. \\
Ce n'est pas ça que je mange. & It is not what I eat. \\
Va préparer notre gombo. & Go and prepare our gombo. \\
Fais venir le propriétaire du dossier. & Go and bring the owner of the file. \\
\hline
\end{tabular}

As in Tables 1 and 2, it can be noted that the expressions here denote nothing relating to corruption in French or in English. Any other French-speaking person seeking a service in Cameroonian offices would need an interpreter to tell him what they need from him. Cameroon English expressions used to ask for bribe in general administration in Cameroon are illustrated in Table 4 below.

Table 4. Specialized language used to ask for bribe in general administration in Cameroon English

\begin{tabular}{ll}
\hline Utterances & Standard British English version \\
\hline Talk fine. & Talk well. \\
Wash my face. & Wash my face. \\
Scratch my hand. & Scratch my hand. \\
Do something. & Do something. \\
Rub my lips/face. & Rub/anoint my lips/face. \\
\hline
\end{tabular}

In the table above, there is almost no difference between the expressions used in Cameroon English and their Standard British English equivalents. Like the ones studied so far, they are so neutral in their literal meaning. Cameroon Pidgin English expressions that are used to ask for bribery in general administration include "chopI chop", "shake skin", "I go see big man", etc. In Standard British English these expressions respectively mean "eat and I eat too", "shake your body", "I am going to see the boss", which denote nothing relating to bribery.

In Cameroon, transport is known as one of the most corrupt sectors. Here, we will not look at what happens in the various offices of the ministry of transport, but specifically at what uniform officers say on roads. Here, police, gendarmes, forest guards and custom officers openly ask and receive bribe. They are popularly called mange-mille (those who eat one thousand CFA francs). If the driver or the passenger in trouble does not have the exact five hundred CFA or one thousand note required, these officers, without shame, can openly give a change to his 5,000 or 10,000 note. On some busy roads, the elements of a special section of the gendarmerie called Routiers, at certain periods of the day, put their helmets in a corner of the road, and use them as a kind of coffer where each driver personally puts a thousand francs before crossing the check point. The table which follows lists some of the expressions they use to ask for this in Cameroon French. 
Table 5. Specialized language used to ask for bribe in transport in Cameroon French

\begin{tabular}{ll}
\hline Utterances & Standard British English version \\
\hline J'ecris? & Should I write? \\
On peut parler? & Can we talk? \\
Comme vous voulez. & As you want. \\
On fait alors comment? & What should we do then? \\
Embrasse-moi. & Embrace me. \\
Tu me prends pour qui? & Whom do you think I am? \\
On va voir le chef. & Let's go and see the head. \\
Qu'est-ce que tu nous-as gardé? & What have you kept for us? \\
\hline
\end{tabular}

The expressions above look so neutral, and at times amusing that no one can imagine them from uniform officers on duties. Expressions such as "embrace me", "what have you kept for us" by police or gendarme officers are simply surprising and ridiculous.

In Cameroon English, the following expressions are used by uniform officers to ask for bribe from road users: "why do you bring me the papers of your car?"; "I am in the sun", "find me something", "fix me", "give me cola". These expressions, like the ones studied in Table5, look so neutral in their literal meaning. Some of the expressions used for the same purpose in Cameroon Pidgin English are illustrated in Table 6 below.

Table 6. Specialized language used to asked for bribe in Cameroon Pidgin English

\begin{tabular}{ll}
\hline Utterances & Standard British English version \\
\hline Massa came see me. & Sir, come and see me. \\
Weti de inside dat book? & What do those particulars contain? \\
Massa na how? & Sir, how do you do? \\
Pa how you de troe me so? & Sir, how can you abandon me? \\
Sun de hot. & The sun is hot. \\
\hline
\end{tabular}

When one looks at these expressions, it is hard to believe that they are uttered by police or gendarme, custom and forest guard officers controlling vehicles, goods and passengers. Expressions such as "the sun is hot" or "Sir, how can you abandon me?" rather look like remarks.

Like transport, from various reports, education is among the most corrupt sectors in Cameroon (see Transparency International Reports 2004 \& 2013). Some of the expressions used to ask for bribe in this sector are listed in the following table.

Table 7. Specialized language used to ask for bribe in education in Cameroon French

\begin{tabular}{ll}
\hline Utterances & Standard British English version \\
\hline Va voir le secrétaire particulier. & Go and see the private secretary. \\
Le délégué/ministre nous attend. & The delegate/minister is waiting for us. \\
Le directeur/proviseur ne reçoit pas. & The director/principal is not receiving. \\
Le directeur/ proviseur n'inscrit plus. & The director/principal is not any longer registering. \\
Les classes sont pleines. & Classes are full. \\
Il faut du papier/des balais. & There need to be some papers/brooms. \\
Nous avons payé pour être ici. & We paid to be here. \\
\hline
\end{tabular}

The expressions above, in their literal meaning, are simply discouraging ones, to a parent who wants to register his child in a school. For example, "classes are full", "the delegate/minister is waiting for us", "the director/principal is not receiving" can simply be decoded respectively as "go elsewhere", "we have an encounter with the delegate/minister", and "the director/principal is busy. Table 8 which follows lists some of the expression used to ask for bribe in education in Cameroon Pidgin English. 
Table 8. Specialized language used to ask for bribe in education in Cameroon Pidgin English

\begin{tabular}{ll}
\hline Utterances & Standard British English version \\
\hline You no say you don came late. & You know that you have come late. \\
You know tin you fi doam. & You know what you can do. \\
Chuck you hand fo you pocket. & Plunge your hand into your pocket. \\
You know weti you go do. & You know what you have to do. \\
My tam no de go fo notin. & I don't waste my time for nothing. \\
Pikin ova plenty. & Classes are overcrowded. \\
Came you one fo 2 o'clock. & Come alone at 2 o'clock. \\
Bring small tin yi name go comot fo list. & Bring a little thing and his/her name will be put on the list. \\
You know say you done take back door. & You know that you are using the back door. \\
Space no de. & There is no place. \\
If way de I go call you. & If there is a possibility I will call you. \\
Space whe remain na delegate & The remaining paces are for the delegate. \\
My throat done dry. & My throat is dry. \\
My belley de empty. & My stomach is empty. \\
Bring some bottle tin. & Bring me a bottle of something. \\
Wuna de sleep? & Are you sleeping? \\
Tock I de hia you. & Speak. I am listening to you. \\
I no go came class but gombo de & I will not come to class, but there is gombo*. \\
Wuna no get connection? & Don't you have relationship? \\
\hline
\end{tabular}

Even if one is a Pidgin English speaker, without an interpretation of a Cameroonian, it would not be possible to get the real meaning of the utterances above. Expressions such as "You know that you have come late" (You know say you done came late), "Speak. I am listening to you" (Tock I de hia you) are as neutral as the remaining ones in their conceptual meaning.

In various Anglophone schools across Cameroon, the English expressions listed in the table that follows are used to ask for bribe from parents or students.

Table 9. Specialized language used to ask for bribe in education in Cameroon English

\begin{tabular}{ll}
\hline Utterances & Standard British English version \\
\hline Find me envelope. & Find an envelope for me. \\
Send your hand under the table. & Stretch your hand under the table. \\
Scratch my hand. & Scratch my hand. \\
Do something. & Do something. \\
Bring me Export. & Bring me a bottle of 33 Export. \\
I need Export. & I need a bottle of 33 Export \\
See me after class. & Meet me after class. \\
Bring our normal thing. & Bring our usual thing/item. \\
Use what you have to get what you want. & Use your available means to achieve your aim. \\
Meet me at that private place. & Meet me at the canteen/drinking place. \\
\hline
\end{tabular}

Like the other expressions analysed so far, the ones in the table above look so neutral, and can be interpreted in their full meaning only by Cameroon English speakers. "Send your hand under the table" or "scratch my hand", like many of the expressions, rather look like a piece of advice or a request for help. The next section looks at the language service seekers use to give bribe.

\subsection{Specialized Language Used to Give Bribe in General Administration, Transport and Education}

Unlike the language used to ask for bribe in Cameroon in the sectors studied so far, that used to give it is not very rich. Indeed, apart from a few exceptions where some Cameroonians at any cost want to benefit from undue advantages and services, in general, Cameroonian service users/seekers are not happy when they buy the service they have the right to. This section examines the few expressions they use to give or to force people to take bribe in general administration, transport and education. Table 10 below illustrates some of the expressions used in Cameroon French in general administration. 
Table 10. Specialized language used to give bribe in general administration in Cameroon French

\begin{tabular}{ll}
\hline Utterances & Standard British English version \\
\hline Voilà votre taxis. & That's for your taxis. \\
On va parler en vrais hommes. & We will talk in true men. \\
Je peux plier la main? & Can I fold the hand? \\
Tendez la main. & Stretch the hand. \\
\hline
\end{tabular}

Like the other expressions studied so far, those contained in table 10 above look very neutral. A phrase such as "voilà votre taxi" (that is for your taxi) expresses more an obligation for someone sending somebody somewhere with the duty to pay for his taxi fare, or a tip than anything relating to bribery. "Tendez la main" (stretch your hand) looks more like an order or a piece of advice.

In education, there are very few expressions that parents and students used to give bribe. When principals, teachers and other school administrators want it, they generally menace parents and students with some of the expression analysed in Tables 7, 8 and 9. Most of the time, the parents and their children have no other option than just giving them what they want without any comments. In Cameroon French, the few expressions that are at times used are "voilà pour un litre d'essence/ votre taxi" (that is for a litre of fuel/your taxi), "ça c'est pour un banc/ un peu de craie" (this is for a desk/ some chalk). In Cameroon Pidgin English, those expressions include "dis na fo you mimbo" (this is for your wine), "dis na fo you petrol/ okada" (this is for your fuel/ bike).

Some of the specialized expressions that drivers use to give bribe to uniform officers in Cameroon Pidgin English are contained in the following table.

Table 11. Specialized language used to give bribe in transport in Cameroon Pidgin English

\begin{tabular}{ll}
\hline Utterances & Standard British English version \\
\hline Na all dis we e de. & It's all it looks like this way. \\
We go see next time. & We will see each other next time. \\
Pa way no de. & Sir, there are no means. \\
Pa na all dis I getam. & Sir, this is all that I have. \\
Chef time de tron. & Sir, times are hard. \\
Na you mimbo dis. & This is your wine. \\
Tekam quench you thirst. & Take this to quench your thirst. \\
\hline
\end{tabular}

Of the above-expressions, apart from "na you mimbo dis" (this is your wine), and "tekam to quench you thirst" (take this to quench your thirst), which indicate that someone is giving something to somebody, none of them denotes anything relating to giving/ receiving something. Even with these two exceptions, one would still wonder what 'wine' and 'quenching the thirst' have to do with the police control.

\section{Discussion and Conclusion}

This paper has tried to study the metalanguage of corruption in the sectors mentioned analysed above. In the various sectors analysed, it is quite striking to observe how simple and neutral expressions have acquired subtle meanings to discuss, ask or give bribe in Cameroon French, Cameroon Pidgin English and Cameroon English. Some of the expressions such as "parle bien" (talk well), "scratch my hand" or "gombo", like many others, cross the boundaries of all the sectors. It should also be pointed out that the expressions listed in this study represent just the tip of the iceberg in the hazy domain of corruption where Cameroon has already 'topped the class' twice, and is still among the most corrupt countries of the world in the classification tables of Transparency International. Apart from throwing some light on this nebulous phenomenon, this study can also serve as an additional instrument to CONAC and other non-governmental structures in charge of curbing corruption in Cameroon. It may help them easily interpret some of the neutral expressions used in Cameroonian administrations to discuss/ask/give bribe.

\section{References}

Atechi, S. N. (2011). Pidgin English in Cameroon: To teach or not to teach. International Journal of Language Studies, 5(1).

Ayafor, M. (1996). An Ortography for Kamtock: A Proposal for a standard script for Cameroon Pidgin English. English Today, 12(4), 13-57. 
Ayafor, M. (2000). Kamtok: The Ultimate Unifying Common National Language for Cameroon. The Carrier Pidgin, 28(1-3), 4-6.

Biloa, E. (1999). Structure phrastique du camfranglais: Etat de la question. In G. Echu \& A. W. Grundstrom (Eds.), Official Bilingualism and Linguistic Communication in Cameroon-Bilinguisme Officiel et Communication Linguistique au Cameroun (pp. 147-175). New York: Peter Lang.

Cerutti, P. O. et al. (2012). Cameroon's Hidden Harvest: Commercial Chainsaw, Logging. Corruption, and Livelihood, Society and Natural Resources: An International Journal, 1(5), 1-5.

Chia, E. (1990). The new Speech Forms of Rapidly Growing City: Pidgin French and Camfranglais in Yaounde. Annales de la Faculté des Lettres et Sciences Humaines, VI(1 \& 2), 102-127. University of Yaounde.

Ferral, C. de (1976). Le Pidgin-English du Cameroon: Présentation Sociolinguistique. Yaounde: Bulletin de L'ALCAM, N 2, ONAREST.

Ferral, C. de (2006). Etudier le Camfranglais: Recueil des donnée et transcription. Le Français en Afrique, 21, 211-218.

Friedrich-Ebert-Stiftung Cameroon. (1999). Crruption in Cameroon. Yaounde: SAAGRAPH.

Kouega, J. P. (2003).Word formative Processes in Camfranglais. World Englishes, 22(4), 511-538. http://dx.doi.org/10.1111/j.1467-971X.2003.00316.x

Lobe Ewane, M. (1989). Cameroun: Le Camfranglais. Diagonales, 10, 33-34.

Mba, G. (2009). Langues et gestion des langues au Cameroun. In F. Eboussi Boulaga (Ed.), l'Etat du Cameroun 2008 (pp. 551-569). Yaounde: Prescriptor and editions terroir.

Mbangwana, P. N. (1983). The scope and role of Pidgin English in Cameroon. In E. L. Koenig et al. (Eds.), A Sociolinguistic profile of Urban Centers in Cameroon (pp. 79-91). Los Angeles: Crossroads Press.

Menang, T. (2004). Cameroon Pidgin English (Kamtock): Phonology. In B. Kortman et al. (Eds.), A Handbook of Varieties of English (pp. 902-916). Berlin, New York: Mouton de Gruyter.

Ndangam, L. N. (2006). Gombo: Bribery and the Corruption of Journalism Ethics in Cameroon. Ecquid Novi: African journalism Studies, 27(2), 179-199. http://dx.doi.org/10.3368/ajs.27.2.179

Ntsobe, A. M. et al. (2008). Le Camfranglais: quelle parlure? Etude linguistique et Sociolinguistique. Frankfurt and Main. Peter Lang.

Peh, K. S., \& Drori, O. (2010). Fighting Corruption to Save the Environment: Cameroon's Experience. Ambio, 39(4), 336-337. http://dx.doi.org/10.1007/s13280-010-0053-0

Quefelec, A. (2005). Le camfranglais, un parler jeune en evolution: du résolecte au Véhiculaire urbain'. In G. Ledegen (Ed.), Les parler jeunes. Terrain et normes diversifiés. Acte de la 8è Table Ronde du Moufia, avril, 2005, Université de la Réunion. Paris: l'Harmattan.

Tiayon Lekobou, C. (1985). Camfranglais: A speech Reality in Cameroon. Unpublished Maîtrise Dissertation, University of Yaounde.

Todd, L. (1974). Pidgins and Creoles. London: Routlege. http://dx.doi.org/10.4324/9780203381199

\section{Notes}

Note 1. Fulfulde is spoken in all the northern part of Cameroon, part of southern Chad and part of northern Nigeria.

Note 2. Ewondo is a Bantu language spoken in the centre of Cameroon; in the south it is called Bulu. In East Cameroon, it is called Mongo Ewondo. In parts of Gabon and the Equatorial Guinea, it is called Fang.

\section{Copyrights}

Copyright for this article is retained by the author(s), with first publication rights granted to the journal.

This is an open-access article distributed under the terms and conditions of the Creative Commons Attribution license (http://creativecommons.org/licenses/by/3.0/). 